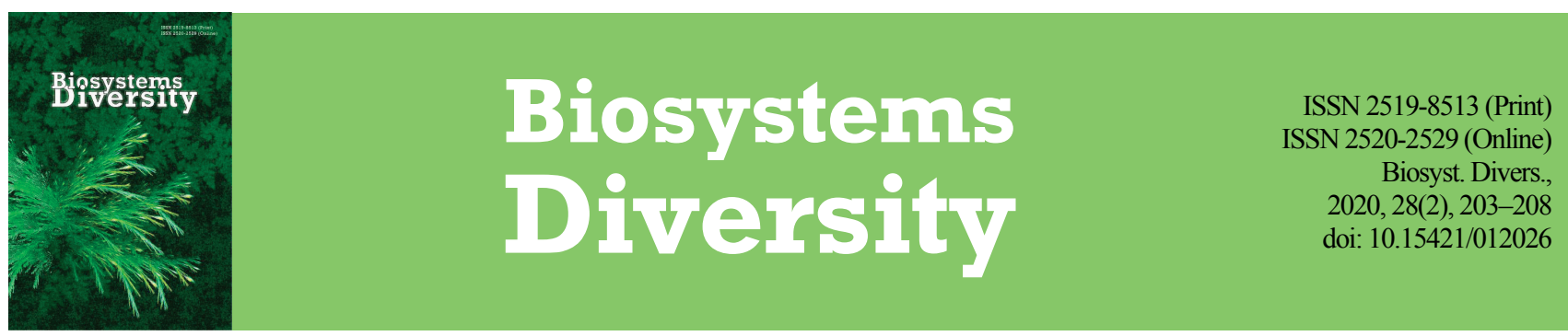

\title{
Influence of multicomponent contamination on the content of photosynthetic pigments in the leaves of woody plants commonly planted for greening of cities
}

\author{
V. P. Bessonova, A. S. Chongova, A. V. Sklyarenko \\ Dnipro State Agrarian and Economic University, Dnipro, Ukraine
}

Article info

Received 10.04.2020

Received in revised form 04.05.2020

Accepted 05.05.2020

Dnipro State Agrarian and Economic University Sergey Efremov st., 25,

Dnipro, 49600, Ukraine

Tel.: +38-066-399-44-47.

E-mail:

a-chongova@ukr.net

\begin{abstract}
Bessonova, V. P., Chongova, A. S., \& Sklyarenko, A. V. (2020). Influence of multicomponent contamination on the content of photosynthetic pigments in the leaves of woody plants commonly planted for greening of cities. Biosystems Diversity, 28(2), $203-208$. doi:10.15421/012026
\end{abstract}

Woody plants, as an important element of optimization of the urban environment, respond negatively to the ever-increasing technogenic pressure in cities. Therefore, it is necessary to assess their vital status, the most sensitive indicator of which being the content of plastid pigments. In this article we analyze the effects of multicomponent contamination on quantitative fluctuation of the level of photosynthetic pigments in the leaves of woody plants and identify sensitive species for the purpose of phytoindication in order to assess the state the environment is currently in. For the purposes of our research we chose the most widespread tree species in the city of Dnipro (Steppe zone of Ukraine), growing in the area of intensive industrial pollution and high levels of emissions by vehicles. We determined the content of photosynthetic pigments (chlorophylls $a$ and $b, a+b$, carotenoids) in the leaves of woody plants during different months of the growing season (June, July, August) and afterwards this data was used to compare the given parameters against the values taken from trees in the control area. The sum of chlorophyll levels $a+b$ for the majority of plants was decreasing compared to the control. A more significant decrease in the content given by the sum of the $a$ and $b$ chlorophyll levels is observed in the assimilation organs of Aesculus hippocastanum L., Pinus pallasiana (D. Don) and Picea abies (L.) H. The most significant changes in the content of pigments in the leaves of plants under study were detected at the end of the growing season (in August). The content of green pigments in the leaves of Robinia pseudoacacia L., Platanus orientalis L. remains virtually unchanged. Under the influence of multicomponent contamination, the amount of pigments in the case of chlorophyll a in the majority of woody plant species decreases more rapidly compared to the control than in the case of chlorophyll $b$. The most noticeable drop in the content of chlorophyll $a$ occurs in the leaves of Betula pendula Roth, Ae. hippocastanum, P. pallasiana, Acer platanoides L. and Tilia cordata Mill. The needles of P. abies and Picea pungens Engelm. 'Glauca' on the contrary suffer from a significant reduction in the concentration of chlorophyll $b$. The species most resistant to multicomponent contamination in terms of changes in the content of chlorophyll in the leaf blade are $R$. pseudoacacia, P. orientalis. The concentration of carotenoids in the leaves of plants such as B. pendula, Ae. hippocastanum, A. platanoides, T. cordata, P. abies is lower than that of species growing in the relatively clean zone. The concentration of pigments in Populus alba L., P. pungens 'Glauca' was higher during all of the months elapsed since the beginning of our study, whereas Ulmus laevis Pall., P. orientalis and R. pseudoacacia - had their concentrations reach an all time high in the second half of the growing season. Therefore, the peculiarities of quantitative fluctuation of photosynthetic pigments in plants, which are characterized by the variable resistance ability against the effects of technogenic multicomponent contamination, have been identified.

Keywords: technogenic conditions; trees; leaf plates; chlorophyll; carotenoids.

\section{Introduction}

The issues concerning urbanization and environmental risks have become global (Lovett et al., 2009; Rai, 2016; Vieira et al., 2018). Increasing urbanization is harming the health of the population due to the increasing technogenic impact on the environment (Schwela, 2000; Host et al., 2012; Salmond et al., 2016).

Green spaces play an important role in the optimization of urban environments (Faly \& Brygadyrenko, 2014; Livesley et al., 2016; Salmond et al., 2016; Vieira, 2018). Not only do they enrich the air with oxygen (Baumgardner et al., 2012), increase its relative humidity (Li et al., 2018) and improve the radiation regime (Yahia, 2018), they also absorb toxic gases (Il'kun, 1978; Getko, 1989; Sergeychik et al., 1998), which can be made bound to the cell compounds, hence becoming involved in the process of metabolism (Escobedo et al., 2011) and thereby become neutralized. Plants serve as a natural filter which absorb dust, which includes heavy metals and other compounds that are detrimental to human health (Bessonova, 1999; Jim \& Chen, 2008; Shulman et al., 2017; Bessonova, 2020).

However, high concentrations of airborne pollutants cause negative changes in the functioning of key systems of a plant organism (Calfapietra et al., 2015; Rai, 2016; Popek et al., 2018). Due to the autotrophic nature of their metabolism, plants are highly sensitive to environmental pollutants (Sergeychik, 1994; Wen et al., 2004). First of all, the negative effect of technogenic factors is manifested through the activity of the photosynthetic apparatus, the most important characteristic of which is the content of plastid pigments (Tarchevs'kyi, 2002; Sen et al., 2017; Bessonova \& Grytsay, 2018; Borisova-Mubarakshina et al., 2019). This indicator responds well to changes in environmental factors, including the techogenic ones (Sergeychik, 1994; Mikhailova \& Berezhnaya, 2000; Bessonova, 2006; Bukharina et al., 2007).

Quantitative fluctuation of the level of plastid pigments as a specific reaction of woody plants has been studied by many researchers. These works are devoted to the analysis of the impact of airborne pollutants originating from a variety of industrial enterprises (Getko, 1989; Bessonova, 2006), as well as the emissions from vehicles (Bessonova et al., 2004; Tsandekova \& Neverova, 2010; Hnativ, 2014). It should be noted that, as a general rule, studies were limited to a small number of species. However, since the combined action of industrial and vehicle emissions can alter the nature of the response of the pigment apparatus in the leaves of trees, it is necessary to learn more about the peculiarities of these changes in a wide range of tree species. The data obtained makes it possible not only to evaluate the conditions of a plantation, the degree of resistance of woody 
plants to the combined effects of technogenic pressure, but also to identify sensitive species for the purposes of phytoindication in order to adequately assess the state of the environment. Chlorophyll content in leaves is known to be a sensitive indicator of environmental pollution (Parmar et al., 2013; Sen et al., 2017).

The aim of this study is to identify quantitative changes in the level of photosynthetic pigments due to the aggregate effect of industrial and vehicle emissions on those species growing in the areas of roadside plantings in the industrial region of the city and to identify the most sensitive plants to be used as indicators for the purpose of assessing the state of the environment.

\section{Materials and methods}

The experiments were conducted at the site near Naberezhna Zavods'ka st. in the city of Dnipro, which is located in Ukraine's Steppe region ( $\left.48^{\circ} 48^{\prime} 39^{\prime \prime} \mathrm{N} 34^{\circ} 90^{\prime} 77^{\prime \prime} \mathrm{E}: 48^{\circ} 48^{\prime} 10^{\prime \prime} \mathrm{N} 35^{\circ} 02^{\prime} 48^{\prime \prime} \mathrm{E}\right)$. The traffic intensity on the site is 49,400 vehicles per day.In addition, depending on the wind direction, industrial emissions from the West, North-East and North-West industrial complexes, in which mainly the metallurgical and machine-building enterprises are located, also end up polluting the investigated area.

Most of these enterprises are ranked with a high atmospheric pollution index (IAP 7.0-14.0 units), whereas at the experimental site the IAP is equal to 11.1 units. According to the classification, the IAP value less than 2.5 corresponds to a clean atmosphere; $2.5-7.5$ - slightly contaminated; 7.6-12.5 - contaminated; $12.6-22.5$ - heavily polluted; $22.6-52.5$ highly polluted; and the one exceeding 52.5 is labeled as "extremely polluted" (Chugai et al., 2018). Atmospheric air at the Zavods'ka Naberezhna st. is contaminated mainly by carbon, nitrogen and sulfur oxides (NO and $\mathrm{NO}_{2}, \mathrm{SO}_{2}$ ), hydrogen sulfide, phenolic compounds, dust containing heavy metal particles ( $\mathrm{Cd}, \mathrm{Fe}, \mathrm{Mn}, \mathrm{Cu}, \mathrm{Ni}, \mathrm{Pb}, \mathrm{Cr}$ ). Vehicle emissions include carbon monoxide, nitrogen, sulfur, benzene, formaldehyde, heavy metals, ammonium etc. (Shmatkov \& Minkov, 2011; Sagittarius, 2019).

Plants that are used as control specimens are grown in the Botanical Garden (Kabar, 2015), which can be considered a relatively clean area, since there are no industrial plants within a $10 \mathrm{~km}$ radius.

11 species of woody plants were selected for our study: Betula pendula Roth., Ulmus laevis Pall., Aesculus hippocastanum L., Acer platanoides L., Tilia cordata Mill., Platanus orientalis L., Robinia psendoacacia L., Populus alba L., Pinus pallasiana (D. Don), Picea abies (L.) H. Karst., Picea pungens Engelm. 'Glauca'.

In order to determine the dynamics of the plastid pigment content, the average sample of leaves for analysis was taken from plants belonging to one of the three categories: young, mature and aging; under similar weather conditions (June 15, July 20, and August 25) from annual shoots from the south-east side of the crown of five model trees at a height of $2.5 \mathrm{~m}$ under the identical lighting conditions. Only the intact parts of the second or third leaf were used in the case of deciduous trees and the first 5-7 needles at a distance of $1 \mathrm{~cm}$ from the base of the annual shoot in the case of coniferous plants. The content of pigments was determined spectrophotometrically using the acetone extract on a SF-2000 spectrophotometer (OKB "Spectrum", Russia, 2007) repeated 4 times in total.

The calculations were performed using the Wettstein equations (Gavrilenko \& Zhigalova, 2003).

$$
\begin{gathered}
C_{a}(m g / L)=9.784 \cdot D_{662}-0.990 \cdot D_{644} ; \\
C_{b}(m g / L)=21.426 \cdot D_{664}-4.650 \cdot D_{642} ; \\
C_{a+b}(m g / L)=5.134 \cdot D_{662} \times 20.436 \cdot D_{644} ; \\
C_{c a r}(m g / L)=4.695 \cdot D_{440.5}-20.436 \cdot C_{a+b} .
\end{gathered}
$$

The content of pigments in the solution was calculated by their concentration, taking into account both the sample and its dilution:

$$
A=C \cdot V / P \cdot 1000 \text {, }
$$

where $\mathrm{A}$ - the pigment content in the plant material $(\mathrm{mg} / \mathrm{g}$ of green weight), $\mathrm{C}$ - concentration of pigments in the extract $(\mathrm{mg} / \mathrm{L}), \mathrm{P}-$ sample of plant material $(\mathrm{g}), \mathrm{V}$ - volume of pigments $(\mathrm{mL})$.

For the purposes of statistical analysis we used IBMSPSS Statistics 22 (IBM, USA, 2013) software suite. Data is represented in the form of mean values and a standard error $(\mathrm{x} \pm \mathrm{SE})$. Statistical analysis was performed by means of analysis of variance (one-way ANOVA). A value of $\mathrm{P}<0.05$ was considered statistically significant.

\section{Results}

In the leaves of most of the species of woody plants that grow under conditions of man-made air pollution, the amount of chlorophyll $a+b$ is less compared to the control (Table 1). The levels of green pigments in leaves of species such as $P$. orientalis and $R$. pseudoacacia under the conditions of technogenic pressure and in a relatively clean zone appear to be remarkably similar throughout the entire duration of the experiment. The level of decline in the concentration of green pigments in experimental plants in comparison with the control during June and July does not exceed $25.0 \%$ on average, with the exception of conifers $-P$. abies and $P$. pallasiana. A significant drop in the content of chlorophyll $a$ and $b$ was detected in August, especially in Ae. hippocastanum, P. pallasiana and P. abies - down $33.2 \%, 32.3 \%$ and $32.8 \%$ respectively, compared to the plants in the control group.

Both the intensity and the type of impact of the pollutants on each of the chlorophyll forms differ depending on the species of trees (Tables 2, 3). In leaves of plants such as $B$. pendula, Ae. hippocastanum, $P$. alba and T. cordata the concentration of chlorophyll $a$ under the conditions of technogenic pressure drops during the growing season more substantially compared with the chlorophyll $b$. In the leaves of $P$. orientalis growing in the areas of outdoor plantings there is even a slight increase in the content of chlorophyll $b$ during June and July compared with the control by $19.6 \%$ and $25.2 \%$, and in $R$. pseudoacacia the changes in the concentration of both forms of pigment are similar. In the needles of $P$. pallasiana there is an almost equal reduction in the content of both forms of chlorophyll, while in the needles of $P$. abies and $P$. pungens, due to the action of multicomponent contamination, the content of chlorophyll $b$ is lower.

Therefore, in the leaves of most of the species of woody plants under study growing in contaminated conditions the level of chlorophyll relative to the control decreases the most in the case of chlorophyll $a$.

The influence of multicomponent contaminants on the carotenoid content also appears to be non-uniform (Table 4). In the case of trees species such as $B$. pendula, Ae. hippocastanum, A. platanoides, $T$. cordata, $P$. abies the amount of yellow pigments decreases relative to the control most significantly during August. However, man-made growth conditions cause a significant increase in the level of this group of plastid pigments in the leaves of $P$. alba, $P$. pungens. The largest difference in the level of carotenoids in the needles of $P$. pungens at both of the sites was detected in June (145.0\%) and August (150.0\%), slightly less in July (139.3\%), and the lowest was in P. alba leaves (needles) during June. The amount of yellow pigments in the leaves of U. laevis, R. pseudoacacia and $P$. orientalis exceeds the control values during July and August, while at the beginning of the growing season (in June) the difference in the actual parameters between the two variants lacks statistical significance (Table 4).

Thus, the concentration of carotenoids in the leaves of some plant species decreases, while in others it actually increases compared to the values obtained from plants growing in the relatively clean zone.

\section{Discussion}

The analysis of the obtained data indicates a lower content of chlorophyll $a+b$ in the leaves of most species of woody plants due to the conditions of technogenic pollution (Table 1) compared to the relatively clean zone. According to the classification, these plants belong to the group of unstable and medium-stable species based on morphometric parameters (Bessonova \& Ivanchenko, 2017). Plants in the leaves of which the level of green pigments does not differ statistically from the one in the control group are included in the tolerant species group. Therefore, the nature of changes in the content of chlorophyll $\mathrm{a}+\mathrm{b}$ to some extent determines the level of stability. Because the decrease in the concentration of these plastid pigments adversely affects the functional activity of the photosynthetic system (Pascal et al., 2005; Suvorova et al., 2011), this might lead to impaired metabolism and consequently a decrease in the natural resistance ability. 
Table 1

Influence of technogenic growth conditions on the content of chlorophyll $a+b$ in the leaves of woody plants growing in the areas of roadside plantings ( $\mathrm{mg} / \mathrm{g}$ of green weight, $\mathrm{x} \pm \mathrm{SE}, \mathrm{n}=4$ )

\begin{tabular}{|c|c|c|c|c|c|c|}
\hline \multirow{2}{*}{ Plant species } & \multicolumn{2}{|r|}{ June } & \multicolumn{2}{|r|}{ July } & \multicolumn{2}{|r|}{ August } \\
\hline & control & technogenic conditions & control & technogenic conditions & control & technogenic conditions \\
\hline Betula pendula & $2.98 \pm 0.12$ & $2.34 \pm 0.14 * *$ & $2.92 \pm 0.06$ & $2.26 \pm 0.11 * *$ & $2.67 \pm 0.11$ & $1.94 \pm 0.06^{* *}$ \\
\hline Ulmus laevis & $3.75 \pm 0.13$ & $3.06 \pm 0.10^{* *}$ & $3.43 \pm 0.03$ & $2.80 \pm 0.09 * *$ & $2.91 \pm 0.07$ & $2.24 \pm 0.05^{* *}$ \\
\hline Aesculus hippocastanum & $2.96 \pm 0.06$ & $2.37 \pm 0.05^{* *}$ & $3.00 \pm 0.08$ & $2.11 \pm 0.05^{* * *}$ & $2.86 \pm 0.08$ & $1.91 \pm 0.04^{* * *}$ \\
\hline Acer platanoides & $2.48 \pm 0.08$ & $1.86 \pm 0.06^{* *}$ & $2.87 \pm 0.11$ & $2.11 \pm 0.10^{* *}$ & $2.80 \pm 0.11$ & $1.96 \pm 0.13^{* *}$ \\
\hline Tilia cordata & $2.93 \pm 0.08$ & $2.41 \pm 0.07 * *$ & $3.18 \pm 0.08$ & $2.29 \pm 0.14^{*}$ & $3.10 \pm 0.12$ & $2.30 \pm 0.09$ \\
\hline Platamus orientalis & $3.06 \pm 0.12$ & $3.31 \pm 0.09$ & $2.62 \pm 0.12$ & $2.77 \pm 0.13$ & $2.67 \pm 0.07$ & $2.49 \pm 0.10$ \\
\hline Robinia pseudoacacia & $2.79 \pm 0.13$ & $2.99 \pm 0.11$ & $3.37 \pm 0.11$ & $3.60 \pm 0.09$ & $2.84 \pm 0.12$ & $2.70 \pm 0.13$ \\
\hline Populus alba & $2.85 \pm 0.08$ & $2.38 \pm 0.07 * *$ & $2.93 \pm 0.08$ & $2.23 \pm 0.06 * *$ & $2.57 \pm 0.06$ & $2.14 \pm 0.04 * *$ \\
\hline Pinus pallasiana & $1.64 \pm 0.03$ & $1.15 \pm 0.03 * *$ & $1.90 \pm 0.05$ & $1.38 \pm 0.04$ & $1.33 \pm 0.05$ & $0.90 \pm 0.04^{* *}$ \\
\hline Picea abies & $1.52 \pm 0.02$ & $1.13 \pm 0.04^{* *}$ & $1.28 \pm 0.03$ & $0.86 \pm 0.03^{* * *}$ & $1.36 \pm 0.03$ & $0.90 \pm 0.03^{* * *}$ \\
\hline P.pungens & $1.44 \pm 0.03$ & $1.19 \pm 0.02^{* * *}$ & $1.28 \pm 0.04$ & $1.07 \pm 0.02 * *$ & $1.36 \pm 0.02$ & $1.08 \pm 0.03^{* *}$ \\
\hline
\end{tabular}

Note: significance levels ${ }_{-}{ }_{-} \mathrm{P}<0.05,{ }^{*}{ }_{-} \mathrm{P}<0.01, * * *-\mathrm{P}<0.001$.

Table 2

Influence of technogenic growth conditions on the content of chlorophyll $a$ in the leaves of woody plants growing in the areas of roadside plantings ( $\mathrm{mg} / \mathrm{g}$ of the green weight, $\mathrm{x} \pm \mathrm{SE}, \mathrm{n}=4)$

\begin{tabular}{|c|c|c|c|c|c|c|}
\hline \multirow{2}{*}{ Plant species } & \multicolumn{2}{|r|}{ June } & \multicolumn{2}{|r|}{ July } & \multicolumn{2}{|r|}{ August } \\
\hline & control & technogenic conditions & control & technogenic conditions & control & technogenic conditions \\
\hline Betula pendula & $2.08 \pm 0.11$ & $1.60 \pm 0.10 * *$ & $1.90 \pm 0.05$ & $1.43 \pm 0.05^{* *}$ & $1.93 \pm 0.06$ & $1.37 \pm 0.07 * *$ \\
\hline Ulmus laevis & $2.55 \pm 0.04$ & $2.04 \pm 0.08 * *$ & $2.30 \pm 0.06$ & $1.77 \pm 0.10^{* *}$ & $2.10 \pm 0.03$ & $1.58 \pm 0.04^{* * *}$ \\
\hline Aesculus hippocastanum & $2.20 \pm 0.08$ & $1.67 \pm 0.12 *$ & $2.21 \pm 0.11$ & $1.66 \pm 0.10^{*}$ & $2.00 \pm 0.06$ & $1.40 \pm 0.08$ \\
\hline Acer platanoides & $1.80 \pm 0.03$ & $1.35 \pm 0.04^{* *}$ & $2.19 \pm 0.06$ & $1.60 \pm 0.03 * *$ & $1.98 \pm 0.07$ & $1.31 \pm 0.06^{* *}$ \\
\hline Tilia cordata & $2.03 \pm 0.03$ & $1.63 \pm 0.12 * *$ & $2.21 \pm 0.11$ & $1.56 \pm 0.09 * *$ & $2.11 \pm 0.12$ & $1.46 \pm 0.08^{* * *}$ \\
\hline Platanus orientalis & $2.05 \pm 0.10$ & $2.09 \pm 0.12$ & $1.98 \pm 0.11$ & $1.97 \pm 0.15$ & $1.82 \pm 0.03$ & $1.74 \pm 0.07$ \\
\hline Robinia pseudoacacia & $1.87 \pm 0.09$ & $1.99 \pm 0.14$ & $2.37 \pm 0.10$ & $2.45 \pm 0.12$ & $2.24 \pm 0.08$ & $1.90 \pm 0.09$ \\
\hline Populus alba & $1.97 \pm 0.09$ & $1.60 \pm 0.12$ & $2.03 \pm 0.05$ & $1.53 \pm 0.04 * * *$ & $1.84 \pm 0.05$ & $1.32 \pm 0.06^{* *}$ \\
\hline Pinus pallasiana & $1.15 \pm 0.04$ & $0.77 \pm 0.02^{* * *}$ & $0.89 \pm 0.02$ & $0.60 \pm 0.03^{* *}$ & $1.04 \pm 0.01$ & $0.71 \pm 0.03^{* *}$ \\
\hline Picea abies & $1.11 \pm 0.01$ & $0.80 \pm 0.02^{* * *}$ & $0.88 \pm 0.02$ & $0.60 \pm 0.02 * *$ & $0.94 \pm 0.03$ & $0.70 \pm 0.02 * * *$ \\
\hline P.pungens & $0.98 \pm 0.05$ & $0.85 \pm 0.03$ & $0.87 \pm 0.04$ & $0.78 \pm 0.05$ & $0.92 \pm 0.02$ & $0.75 \pm 0.03^{* *}$ \\
\hline
\end{tabular}

Note: significance levels $*_{-} \mathrm{P}<0.05,{ }^{*}{ }_{-}-\mathrm{P}<0.01, *^{*} *_{-} \mathrm{P}<0.001$.

Table 3

Influence of technogenic growth conditions on the content of chlorophyll $b$ in the leaves of woody plants growing in the areas of roadside plantings ( $\mathrm{mg} / \mathrm{g}$ of green weight, $\mathrm{x} \pm \mathrm{SE}, \mathrm{n}=4$ )

\begin{tabular}{|c|c|c|c|c|c|c|}
\hline \multirow{2}{*}{ Plant species } & \multicolumn{2}{|r|}{ June } & \multicolumn{2}{|r|}{ July } & \multicolumn{2}{|r|}{ August } \\
\hline & control & technogenic conditions & control & technogenic conditions & control & technogenic conditions \\
\hline Betula pendula & $0.90 \pm 0.02$ & $0.74 \pm 0.02 *$ & $0.92 \pm 0.03$ & $0.83 \pm 0.04$ & $0.74 \pm 0.01$ & $0.60 \pm 0.02 * * *$ \\
\hline Ulmus laevis & $1.20 \pm 0.02$ & $1.02 \pm 0.02 * * *$ & $1.13 \pm 0.02$ & $1.03 \pm 0.01^{*}$ & $0.81 \pm 0.02$ & $0.66 \pm 0.01 * *$ \\
\hline Aesculus hippocastanum & $0.76 \pm 0.02$ & $0.70 \pm 0.03$ & $0.79 \pm 0.02$ & $0.61 \pm 0.01 * * *$ & $0.86 \pm 0.04$ & $0.66 \pm 0.07$ \\
\hline Acer platanoides & $0.68 \pm 0.01$ & $0.51 \pm 0.01 * * *$ & $0.72 \pm 0.02$ & $0.53 \pm 0.01 * * *$ & $0.82 \pm 0.02$ & $0.65 \pm 0.03^{*}$ \\
\hline Tilia cordata & $0.90 \pm 0.01$ & $0.78 \pm 0.02 *$ & $0.97 \pm 0.04$ & $0.73 \pm 0.03^{*}$ & $0.99 \pm 0.02$ & $0.84 \pm 0.01 * *$ \\
\hline Platanus orientalis & $1.02 \pm 0.03$ & $1.22 \pm 0.04^{*}$ & $0.64 \pm 0.03$ & $0.80 \pm 0.02 * *$ & $0.85 \pm 0.04$ & $0.78 \pm 0.03$ \\
\hline Robinia pseudoacacia & $0.92 \pm 0.04$ & $1.00 \pm 0.02$ & $1.00 \pm 0.05$ & $1.15 \pm 0.04$ & $0.80 \pm 0.06$ & $0.80 \pm 0.05$ \\
\hline Populus alba & $0.88 \pm 0.01$ & $0.78 \pm 0.01 *$ & $0.80 \pm 0.02$ & $0.70 \pm 0.02 *$ & $0.73 \pm 0.01$ & $0.62 \pm 0.01 * *$ \\
\hline Pinus pallasiana & $0.49 \pm 0.01$ & $0.38 \pm 0.02 *$ & $0.49 \pm 0.02$ & $0.30 \pm 0.01 * * *$ & $0.52 \pm 0.01$ & $0.34 \pm 0.01 * * *$ \\
\hline Picea abies & $0.41 \pm 0.03$ & $0.33 \pm 0.02$ & $0.40 \pm 0.02$ & $0.26 \pm 0.02 *$ & $0.42 \pm 0.02$ & $0.20 \pm 0.03^{* *}$ \\
\hline P.pungens & $0.46 \pm 0.01$ & $0.34 \pm 0.02 * * *$ & $0.41 \pm 0.01$ & $0.29 \pm 0.02 * *$ & $0.46 \pm 0.01$ & $0.33 \pm 0.01 * * *$ \\
\hline
\end{tabular}

Note: significance levels * $-\mathrm{P}<0.05, * *-\mathrm{P}<0.01, * * *-\mathrm{P}<0.001$.

Table 4

Influence of technogenic growth conditions on the content of carotenoids in the leaves (needles) of woody plants ( $\mathrm{mg} / \mathrm{g}$ of green weight, $\mathrm{x} \pm \mathrm{SE}, \mathrm{n}=4$ )

\begin{tabular}{|c|c|c|c|c|c|c|}
\hline \multirow{2}{*}{ Plant species } & \multicolumn{2}{|r|}{ June } & \multicolumn{2}{|r|}{ July } & \multicolumn{2}{|r|}{ August } \\
\hline & control & technogenic conditions & control & technogenic conditions & control & technogenic conditions \\
\hline Betula pendula & $0.422 \pm 0.012$ & $0.341 \pm 0.007^{*}$ & $0.572 \pm 0.015$ & $0.431 \pm 0.011 * *$ & $0.480 \pm 0.005$ & $0.351 \pm 0.006$ \\
\hline Ulmus laevis & $0.352 \pm 0.015$ & $0.301 \pm 0.015$ & $0.251 \pm 0.010$ & $0.323 \pm 0.008^{* *}$ & $0.242 \pm 0.004$ & $0.372 \pm 0.007 * * *$ \\
\hline Aesculus hippocastanum & $0.271 \pm 0.011$ & $0.210 \pm 0.005^{* *}$ & $0.331 \pm 0.011$ & $0.234 \pm 0.014 * * *$ & $0.354 \pm 0.011$ & $0.232 \pm 0.008 * *$ \\
\hline Acer platanoides & $0.360 \pm 0.021$ & $0.312 \pm 0.015$ & $0.301 \pm 0.015$ & $0.221 \pm 0.012 * *$ & $0.321 \pm 0.009$ & $0.212 \pm 0.010^{* *}$ \\
\hline Tilia cordata & $0.321 \pm 0.010$ & $0.281 \pm 0.007^{*}$ & $0.402 \pm 0.009$ & $0.350 \pm 0.004^{* * *}$ & $0.373 \pm 0.011$ & $0.280 \pm 0.007 * *$ \\
\hline Platamus orientalis & $0.241 \pm 0.012$ & $0.253 \pm 0.014$ & $0.350 \pm 0.005$ & $0.420 \pm 0.003 * * *$ & $0.301 \pm 0.006$ & $0.361 \pm 0.008 * *$ \\
\hline Robinia pseudoacacia & $0.270 \pm 0.011$ & $0.291 \pm 0.009$ & $0.282 \pm 0.010$ & $0.361 \pm 0.005^{* *}$ & $0.292 \pm 0.009$ & $0.392 \pm 0.011 * *$ \\
\hline Populus alba & $0.251 \pm 0.009$ & $0.291 \pm 0.007^{*}$ & $0.241 \pm 0.003$ & $0.312 \pm 0.002 *$ & $0.202 \pm 0.012$ & $0.291 \pm 0.007 * *$ \\
\hline Pinus pallasiana & $0.183 \pm 0.011$ & $0.120 \pm 0.006^{* *}$ & $0.251 \pm 0.005$ & $0.160 \pm 0.004^{* * *}$ & $0.221 \pm 0.008$ & $0.152 \pm 0.011^{*}$ \\
\hline Picea abies & $0.190 \pm 0.005$ & $0.160 \pm 0.007^{*}$ & $0.180 \pm 0.006$ & $0.143 \pm 0.003^{*}$ & $0.180 \pm 0.005$ & $0.120 \pm 0.006^{* *}$ \\
\hline P.pungens & $0.201 \pm 0.010$ & $0.292 \pm 0.006^{* * *}$ & $0.172 \pm 0.008$ & $0.231 \pm 0.004^{* * *}$ & $0.161 \pm 0.004$ & $0.243 \pm 0.008^{* *}$ \\
\hline
\end{tabular}

Note: significance levels ${ }^{*}-\mathrm{P}<0.05,{ }^{*}{ }_{-}-\mathrm{P}<0.01,{ }^{*} *{ }_{-} \mathrm{P}<0.001$. 
As can be seen from Table 1,2, the vast majority of plants growing under the conditions of environmental pollution are characterized by a more significant reduction in chlorophyll $a$ content compared with chlorophyll $b$. It should be noted that chlorophyll $a$ is the main pigment that is directly involved in photosynthetic transformations. Other pigments act as a light-harvesting antenna and transmit energy to chlorophyll $a$ (Pascal et al., 2005). In the process of light harvesting, energy, due to the absorption of light quanta by the singlet state of the pigment molecules bound to the antenna proteins, is transferred from the carotenoids to the chlorophylls, then from the chlorophyll $b$ to the chlorophyll $a$ and up the chain from the chlorophyll $a$ to the reaction center of the photosystem (Croce et al., 2001). It is believed that the decrease in the level of chlorophyll $a$ can be seen as an indicator of air pollution (Barakhteneva \& Nikolaevsky, 1988). According to our research, the most sensitive plants are B. pendula, Ae. hippocastanum, P. pallasiana, A. platanoides, T. cordata, while the data obtained during August appears to be more illustrative of the phenomena.

Non-uniform changes in the content of chlorophyll $a$ and chlorophyll $b$ lead to a shift in the ratio $a$ over $b$, which indicates a violation of the stoichiometric ratio between the complexes of the reaction centers of photosystems and CCS II (Lindahl et al., 1995; Dimova \& Golovko, 2007). Correspondingly, in the case of the most resistant species of them all $-P$. orientalis - one can actually observe an increase in the content of chlorophyll $b$ compared with chlorophyll $a$, whereas in the case of R. pseudoacacia no quantitative changes in the levels of either of the forms of green pigments relative to control ever take place.

In the case of coniferous tree species such as $P$. abies and $P$. pungens 'Glauca', we found a greater decrease in chlorophyll $b$ content compared with chlorophyll $a$. It is important to note that in the areas of roadside plantings in a relatively clean part of the city (at a distance of up to $10 \mathrm{~km}$ away from the industrial enterprises) $P$. pungens of the 'Viridis' cultivar suffers from more significant detrimental effects correlated with the decrease of the content of chlorophyll $a$ (Bessonova \& Ponomareva, 2017), which may suggest the importance of taking the type of pollutants and their ratios into account and not just the response of a given plant species to environmental pollution.

Minor changes in the amount of chlorophyll $b$ in comparison with chlorophyll $a$ in the leaves of a number of plants growing in the areas with a greater degree of technogenic pressure, and also the stability in its content in the leaves of $P$. orientalis and $R$. pseudoacacia, can be regarded as positive. Publications indicate the ability of chlorophyll $b$ to perform protective functions (Shlyk, 1963; Tyuterova et al., 2017). In particular, the involvement of chlorophyll $b$ in supporting the supramolecular organization of thylakoid membranes has been described (Miller et al., 1976). It should also be noted that mutated species lacking chlorophyll $b$ tend to experience strong oxidative stress, primarily due to the high production of singlet oxygen (Dall'Osto et al., 2010). Chlorophyll $b$ is involved in the transfer of approximately $50.0 \%$ of the absorbed energy to chlorophyll $a$ (Formaggio et al., 2001).

Referring to the literary sources that mention the characteristics of the effect of environmental pollutants on the content of chlorophyll $a$ and chlorophyll $b$, it is necessary to note the ambiguity and non-uniformity of the results obtained. According to some researchers, chlorophyll $a$ is more sensitive than chlorophyll $b$ to industrial emissions (Frolov \& Horyshyna, 1982; Korshikov, 1996; Bukharina et al., 2013; Kulagin \& Shakhmetova, 2016). Whereas McNatly \& Newman (1964) believe that a more significant decrease in the content of chlorophyll $a$ is due to inhibition of the synthesis of its precursors, in particular protochlorophyll.

Although Tarabrin (1980) notes that chlorophyll $a$ undergoes more significant changes as far as quantitative parameters are concerned in the case of the influence of inorganic emissions, according to the same author, the impact on the content of chlorophyll $b$ in both damaged and undamaged portions of leaves is deemed more considerable in the case of environmental pollution by organic compounds. In the model experiments of Il'kun (1978), during the fumigation of plants by $\mathrm{SO}_{2}, \mathrm{Cl}_{2}$, there was a greater destruction of chlorophyll $b$ compared with chlorophyll $a$. The same results were obtained regarding the effects of ozone on plants (Nobel, 1974). Significant reduction of chlorophyll $b$ content in the leaves of virgin woody plants and net photosynthesis under the conditions of priority con- tamination with chlorine compounds was observed by Bessonova \& Yakovleva-Nosar' (2004).

Some researchers have noted a greater sensitivity of chlorophyll $b$ in the leaves (needles) of $P$. abies due to anthropogenic factors (Tuzhilkina et al., 1998; Ovechkina \& Shakhmetova, 2015). Gnatov (2014) observed a more rapid decrease in the content of chlorophyll $b$ in the leaves of A. platanoides in street plantations compared to the trees growing in parks against the background of reduction of all forms of pigments. This helped to obtain a high calculated ratio of chlorophyll $a$ to chlorophyll $b$. Similar results were obtained by Tymko (2016) in the leaves of B. pendula.

Thus, the non-uniform effects of environmental pollutants on the changes in the content of chlorophyll $a$ and $b$ in different plant species depends not only on the species-specific characteristics of the plants, but also on the chemical nature of the toxicants and their quantitative ratios in the composition of the multicomponent pollutants and may be the result of various effects that lead to the degradation of these forms of chlorophyll, their biosynthesis and interconversion.

Quantitative fluctuation of the level of carotenoids is of great interest in the study of the effects of anthropogenic pollution on changes in the plant pigment fund, since they play an important role in the functioning of the photosynthetic apparatus. As can be seen from Figure 3, under the conditions of technogenic pollution, the amount of carotenoids in the leaves of such plants as B. pendula, Ae. hippocastanum, A. platanoides, $T$. cordata, and especially in pines of the $P$. pallasiana species, decreases, which may adversely affect the photosynthetic processes of these plants, since these pigments happen to be the main components of the antenna complex. The light-harvesting function of carotenoids is energetic in nature because they transfer the absorbed energy of light to the singlet excited level of chlorophyll (Ladygin \& Shirshikova, 2006).

The content of carotenoids in the assimilation organs of $P$. orientalis, R. pseudoacacia, P. alba and P. pungens in the experimental area, on the contrary, is higher compared to the control. The first two species belong to the category of trees "very resistant" to the emissions of metallurgical enterprises and other pollutants, the other two being simply "resistant" (Il'kun, 1971; Bessonova \& Ivanchenko, 2017). It should be noted that the function of carotenoids is to act as antioxidants. They reduce oxidative stress by converting triplet chlorophyll and singlet oxygen to the ground state, while transitioning to the triplet excited state with subsequent energy dissipation in the form of heat (Frank et al., 1999; Edge \& Truscott, 2010; Smolikova \& Medvedev, 2015). These plastid pigments vigorously eliminate excess reactive oxygen species (Giil \& Tuteja, 2010), protecting pigments and unsaturated lipid fatty acids (Edge et al., 1997), chloroplast membranes (Havaux, 1998; Pinzino et al., 1999) from the destructive action of free radicals interacting with them (Kurchi, 2000). It should be noted that the activation of free radical processes and the increase in the number of reactive oxygen species in plant cells can all be viewed as a response to stress-inducing effects, including the influence of technogenic pollutants (Asada et al., 1974; Bessonova, 1999, 2006; Kolupaev \& Karpets, 2019).

Therefore, the increase in the level of carotenoids in the assimilation organs of resistant plant species in response to contaminants is an adaptive response aimed at increasing the stability of the photosynthetic apparatus.

\section{Conclusions}

Under the conditions of technogenic pressure, the most significant decrease in the content of chlorophyll $a+b$ compared to the control is observed in the leaves of species of woody plants such as Ae. hippocastanum, P. pallasiana, P. abies. In the case of the assimilation organs of most of the species under study, the content of chlorophyll $a$ is significantly lower than that of chlorophyll $b$ relative to control values. The preservation of the concentration of chlorophylls in leaves of $P$. orientalis and $R$. pseudoacacia under the technogenic growth conditions at almost the same level as the control values indicates the stability of the photosynthetic apparatus of these plants.

The most sensitive indicators of environmental pollution with multicomponent emissions ordered by the level of change in chlorophyll $a$ content in the leaves of plant species are B. pendula, Ae. hippocastanum, P. pallasiana, A. platanoides and T. cordata. 
The amount of carotenoids in the leaf blades of most species of the plants investigated decreases compared to the control. In the case of trees such as $U$. laevis, $P$. orientalis and $R$. pseudoacacia, their carotenoid levels increase in these organs in the second half of the growing season, while in the case of $P$. alba and $P$. pungens carotenoid levels were up during the entire period of the study, which can be viewed as an adaptive response of the pigment complex to the detrimental effects of airborne multicomponent pollutants.

\section{References}

Asada, K., Kiso, K., \& Yoshikawa, R. (1974). Univalent reduction of molecular oxygen by spinach chloroplasts on illumination. Journal of Biological Chemistry, 249(7), 2175-2181.

Barahteneva, L. A., \& Nikolaevskij, B. C. (1988). Vlijanie sernistogo gaza na fotosintez rastenij [The effect of sulfur dioxide on plant photosynthesis]. Nauka, Novosibirsk (in Russian)

Baumgardner, D., Varela, S., Escobedo, F. J., Chacalo, A., \& Ochoa, C. (2012). The role of a peri-urban forest on air quality improvement in the Mexico City megalopolis. Environmental Pollution, 163, 174-183.

Bessonova, V. P. (1999). Citofiziologicheskie effekty vozdejstvija tjazhelyh metallov na rost i razvitie rastenij: monografija [Cytophysiological effects of heavy metals on plant growth and development]. ZGU, Zaporozhe (in Russian).

Bessonova, V.P. (2006). Vlijanie tjazhelyh metallov na fotosintez rastenij [The effect of heavy metals on plant photosynthesis]. DGAU, Dnepropetrovsk (in Russian).

Bessonova, V. P., \& Ivanchenko, O. Y. (2007). Otsinka funktsionalnoho stanu derevnykh nasadzhen parkiv mista Dnipro za pokaznykamy intensyvnosti vilnoradykalnoho okysnennia ta vmistu prolinu [Assessment of the functional state of tree stands of Dnipro parks by the intensity of free radical oxidation and proline content]. Ukrainian Journal of Ecology, 7(3), 146-153 (in Ukrainian).

Bessonova, V. P., \& Yakovleva-Nosar, S. O. (2004). Stan asymiliatsiinoho aparatu i netto-fotosyntez virhinilnykh derevnykh roslyn za umov priorytetnoho zabrudnennia khlorystymy spolukamy [State of assimilation apparatus and net photosynthesis of virgin woody plants under priority contamination by chlorine compounds]. Problemy Ekologii i Ohrany Prirody Tehnogennogo Regiona, 4, 157-162 (in Ukrainian).

Bessonova, V. P., Kapelyush, N. V., Ovcharenko, S. V., \& Pismenchuk, V. D. (2004). Vlijanie polikomponentnyh vybrosov avtomobil'nogo transporta na soderzhanie hlorofilla $\mathrm{v}$ list'jah drevesnyh rastenij [The effect of multicomponent emissions of automobile transport on the content of chlorophyll in the leaves of woody plants]. Biuleten Derzhavnoho Nikitskoho Botanichnoho Sadu, 89, 73-75 (in Russian).

Bessonova, V., \& Grytsay, Z. (2018). Content of plastid pigments in the needles of Pinus pallasiana D. Don in different forest growth conditions of antierosion planting. Ekológia (Bratislava), 37(4), 338-344.

Bessonova, V., Dzhyhan, O., Ivanchenko, O., \& Ponomarova, O. (2020). The phytotoxic effects of lead, cadmium and sodium chloride on the morphological and characteristics of ornamental herbaceous plants. In: Landi, M., Shemet, S. A., \& Fedenko, V. S. (Eds.). Metal toxicity in higher plants. Nova Science Publishers, New York. Pp. 157-202.

Borisova-Mubarakshina, M. M., Vetoshkina, D. V., \& Ivanov, B. N. (2019). Antioxidant and signaling functions of the plastoquinone pool in higher plants. Physiologia Plantarum, 166, 181-198.

Buharina, I. L., Kuzmin, P. A., \& Gibadulina, I. I. (2013). Analiz soderzhanija fotosinteticheskih pigmentov v list'jah drevesnyh rastenij v uslovijah gorodskoj sredy (g. Naberezhnye Chelny) [Analysis of the content of photosynthetic pigments in the leaves of woody plants in an urban environment (Naberezhnye Chelny)]. Vestnik Udmurdskogo Universiteta, 1, 20-25 (in Russian).

Buharina, I. L., Povarnicina, T. M., \& Vedernikov, K. E. (2007). Ekologo-biologicheskie osobennosti drevesnyh rastenij $\mathrm{v}$ urbanizirovannoj srede [Ecological and biological characteristics of woody plants in an urbanized environment]. IzhGSHA, Izhevsk (in Russian).

Calfapietra, C., Peñuelas, J., \& Niinemets, Ü. (2015). Urban plant physiology: Adaptation-mitigation strategies under permanent stress. Trends in Plants Science, 20(2), 72-75.

Candekova, O. L., \& Neverova, O. A. (2010). Vlijanie vybrosov avtotransporta na pigmentnyj kompleks list'ev drevesnyh rastenij [The effect of vehicle emissions on the pigment complex of leaves of woody plants]. Izvestija Samarskogo Nauchnogo Centra RAN, Biologicheskie Resursy: Flora, 1(3), 853856 (in Russian)

Chuhai, A. V., Cherniakova, O. I., \& Bazyka, Y. V. (2018). Analiz tekhnohennoho navantazhennia na povitrianyi basein okremykh promyslovo-miskykh ahlomeratsii skhidnoi Ukrainy (na prykladi mista Dnipro) [The analysis of the current navantazhennia on povitrianyi basein okremykh promyslovo-miskykh ahlomeratsii skhidnoi Ukrainy (on the example of the Dnipro city)]. Visnyk Kharkiv- s'kogo Nacional'nogo Universitetu Imeni V. N. Karazina, Ekolohiia, 19, 75-81 (in Ukrainian).

Croce, R., Miller, M. G., Bassi, R., \& Holzwath, A. R. (2001). Carotenoid-tochlorophyll energy transfer in recombinant major light-harvesting complex (LHCII) of higher plants. I. Femtosecond transient absorption measurements. Biophysical Journal, 80(2), 901-915.

Dall'Osto, L., Cazzaniga, S., Havaux, M., \& Bassi, R. (2010). Enhanced photoprotection by protein-bound vs free xanthophyll pools: A comparative analysis of chlorophyll b and xanthophyll biosynthesis mutants. Molecular Plant, 3(3), 576-593.

Dymova, V., \& Golovko, T. K. (2007). Sostojanie pigmentnogo apparata rastenij zhivuchki polzuchej v svjazi s adaptaciej k svetovym uslovijam proizrastanija [The state of the pigment apparatus of tenacious creeping plants in connection with adaptation to the light conditions of growth]. Fiziologija Rastenij, 54(1), 47-53 (in Russian).

Edge, R., \& Truscott, G. (2010). Properties of carotenoid radicals and excited states and their potential role in biological systems. In: Landrum, J. T. (Ed.). Carotenoids: Physical, chemical, and biological functions and properties. Taylor \& Francis. Pp. 283-307.

Edge, R., McGarvey, D. J., \& Truscott, T. G. (1997). The carotenoids as anti-oxidants - a review. Journal of Photochemistry Photobiology B, 41(3), 189-200.

Escobedo, F. J., Kroeger, T., \& Wagner, J. E. (2011). Urban forests and pollution mitigation: Analyzing ecosystem services and disservices. Environmental Pollution, 159(8-9), 2078-2087.

Faly, L. I., \& Brygadyrenko, V. V. (2014). Patterns in the horizontal structure of litter invertebrate communities in windbreak plantations in the steppe zone of the Ukraine. Journal of Plant Protection Research, 54(4), 414420.

Formaggio, E., Cinque, G., \& Bassi, R. (2001). Functional architecture of the major light-harvesting complex from higher plants. Journal of Molecular Biology, 314(5), 1157-1166.

Frank, H. A. (1999). Incorporation of carotenoids into reaction center and lightharvesting pigmen-protein complexes. In: Frank, H. A., Young, A., Britton, G., \& Cogdell, R. J. (Eds.). Photochemistry of carotenoids. Kluwer Academic Publishers, Dordrecht. Pp. 235-244.

Frolov, A. K., \& Gorishina, T. K. (1982). Osobennosti fotosinteticheskogo apparata nekotoryh drevesnyh porod $\mathrm{v}$ gorodskih uslovijah [Features of the photosynthetic apparatus of some tree species in urban environments]. Botanicheskij Zhurnal, 67(5), 599-609 (in Russian).

Gavrilenko, V. F., \& Zhigalova, T. V. (2003). Bol'shoj praktikum po fotosintezu [Great workshop on photosynthesis]. Akademija, Moscow (in Russian).

Getko, N. V. (1989). Rastenija v tehnogennoj srede [Plants in a technogenic environment]. Nauka i Tehnika, Minsk (in Russian).

Gill, S. S., \& Tuteja, N. (2010). Reactive oxygen species and antioxidant machinery in abiotic stress tolerance in crop plants. Plant Physiology and Biochemistry, 48(12), 909-930.

Havaux, M. (1998). Carotenoids as membrane stabilizers in chloroplasts. Trends in plant science, 3(4), 147-151.

Hnativ, P. S. (2014). Funktsionalna diahnostyka v dendrolohii [Functional diagnostics in dendrology]. Kamula, Lviv (in Ukrainian).

Host, S., Chatignoux, E., Leal, C., \& Grémy, I. (2012). Health risk assessment of traffic-related air pollution near busy roads. Revue d'Epidemiologie et de Sante Publique, 60(4), 321-330 (in French).

Il'kun, G. M. (1971). Gazoustojchivost' rastenij [Gas resistance of plants]. Naukova Dumka, Kiev (in Russian).

Il'kun, G. M. (1978). Zagrjazniteli atmosfery i rastenija [Air pollutants and plants]. Naukova Dumka, Kiev (in Russian).

Jim, C. Y., \& Chen, W. Y. (2008). Assessing the ecosystem service of air pollutant removal by urban trees in Guangzhou (China). Journal of Environmental Economics and Management, 88(4), 665-676.

Kabar, A. M. (2015). Kataloh roslyn Botanichnoho sadu Dnipropetrovskoho natsional'noho universytetu imni Olesia Honchara [Catalog of Plants of the Botanical Garden of Oles Honchar Dnipropetrovsk National University]. Lira, Dnipropetrovsk (in Ukrainian).

Kolupaev, Y. E., \& Karpec, Y. V. (2019). Aktivnye formy kisloroda, antioksidanty i ustojchivost' rastenij k dejstviju stressorov [Active forms of oxygen, antioxidants and plant resistance to stress]. Logos, Kiev (in Russian).

Korshikov, I. I. (1996). Adaptacija rastenij k uslovijam tehnogenno zagrjaznennoj sredy [Adaptation of plants to the conditions of anthropogenic polluted environment]. Naukova Dumka, Kiev (in Russian).

Kulagin, A. Y., \& Shahmetova, R. I. (2016). Osobennosti soderzhanija fotosinteticheskih pigmentov $\mathrm{v}$ hvoe sosny obyknovennoj $\mathrm{v}$ uslovijah neftjanogo zagrjaznenija [Features of the content of photosynthetic pigments in the needles of common pine under oil pollution]. Izvestija Samarskogo Nauchnogo Centra RAN, 18(2), 434437 (in Russian).

Kurchii, B. O. (2000). Abstsyzova kyslota yak kintsevyi produkt antyokysniuval'noho metabolizmu ksantofiliv, zumovlenoho diieiu dykvatu [Abscisic acid as a final product of the antioxidant metabolism of xanthophylls caused by the action of diquat]. Fiziologiya i Biohimiya Kultumyh Rastenij, 32(4), 334-338 (in Ukrainian). 
Ladygin, V. G., \& Shirshikova, G. N. (2006). Sovremennoe predstavlenie o funkcional'noj roli karotinoidov v hloroplastah eukariot [Current understanding of the functional role of carotenoids in eukaryotic chloroplasts]. Zhurnal Obshhej Biologi, 67(3), 163-189 (in Russian).

Li, Z., Chen, D., Cai, S., \& Che, S. (2018). The ecological services of plant communities in parks for climate control and recreation - A case study in Shanghai, China. PLoS One, 13(4), e0196445.

Lindahl, M., Yang, D. H., \& Anderson, B. (1995). Regulatory proteolysis of the major light-harvesting chlorophyll $\mathrm{a} / \mathrm{b}$ protein complex of photosystem II by a light-induced membrane associated enzymic system. European Journal of Biochemistry, 231, 503-509.

Livesley, S. J., McPherson, G. M., \& Calfapietra, C. (2016). The urban forest and ecosystem services: Impacts on urban water, heat, and pollution cycles at the tree, street, and city scale. Journal of Environmental Quality, 45(1), 119-124.

Lovett, G. M., Tear, T. H., Evers, D. C., Findlay, S. E., Cosby, B. J., Dunscomb, J. K., Driscoll, C. T., \& Weathers, K. C. (2009). Effects of air pollution on ecosystems and biological diversity in the Eastern United States. Annals of the New York Academy of Sciences, 1162, 99-135.

McNutly, I. B., \& Newman, D. W. (1964). Mechanism of fluoride induced chlorosis. Plant Physiology, 36(4), 121-124.

Mihajlova, T. A., \& Berezhnaya, N. S. (2000). Ocenka sostojanija sosnovyh lesov pri dlitel'nom vozdejstvii vybrosov aljuminievogo zavoda [Assessment of the state of pine forests during the long-term exposure to emissions from an aluminum smelter]. Geografija i Prirodnye Resursy, 1, 43-50 (in Russian).

Miller, R. R., Miller, G. J., \& Mclntyre, K. R. (1976). The light-harvesting chlorophyll-protein complex of photosystem II. Its location in the photosynthetic membrane. Journal of Cell Biology, 71(2), 624-638.

Nobel, P. (1974). Ozone effects on chlorophylls a and b. Paturwissenschaften, 2, 80-81.

Ovechkina, V. S., \& Shahmetova, R. I. (2015). Vlijanie antropogennyh faktorov na soderzhvnie pigmentov sosny obyknovennoj $\mathrm{v}$ letnij period na territorii Nizhevartovskogo rajona [The influence of anthropogenic factors on the content of pigments of Scots pine in the summer in the Nizhevartovsky district]. Izvestija Samarskogo Nauchnogo Centra RAN, 17(6), 236-241 (in Russian).

Parmar, P., Nilima, K., \& Vinay, S. (2013). Structural and functional alterations in photosynthetic apparatus of plants under cadmium stress. Botanica Studies, $54(45), 1-6$.

Pascal, A. A., Liu, Z., Broess, K., van Oort, B., van Amerongen, H., Wang, C. Horton, P., Robert, B., Chang, W., \& Ruban, A. (2005). Molecular basis of photoprotection and control of photosynthetic light-harvesting. Nature, 436(7047), 134-137.

Pinzino, C., Capocchi, A., Galleschi, L., Saviozzi, F., Nanni, B., \& Zandomeneghi, M. (1999). Aging, free radicals, and antioxidants in wheat seeds. Journal of Agricultural and Food Chemistry, 47(4), 1333-1339.

Popek, R., Przybysz, A., Gawrońska, H., Klamkowski, K., \& Gawroński, S. W. (2018). Impact of particulate matter accumulation on the photosynthetic apparatus of roadside woody plants growing in the urban conditions. Ecotoxicology and Environmental Safety, 163, 56-62.

Rai, P. K. (2016). Impacts of particulate matter pollution on plants: Implications for environmental biomonitoring. Ecotoxicology and Environmental Safety, $129,120-136$

Salmond, J. A., Tadaki, M., Vardoulakis, S., Arbuthnott, K., Coutts, A., Demuzere, M., Dirks, K. N., Heaviside, C., Lim, S., Macintyre, H., McInnes, R. N., \& Wheeler, B. W. (2016). Health and climate related ecosystem services provided by street trees in the urban environment. Environmental Health, 15(Suppl 1), 36.

Schwela, D. (2000). Air pollution and health in urban areas. Reviews on Environmental Health, 15(1-2), 13-42.

Sen, A., Khan, I., Kundu, D., Das, K., \& Datta, J. K. (2017). Ecophysiological evaluation of tree species for biomonitoring of air quality and identification of air pollution-tolerant species. Environmental Monitoring and Assessment, 189(6), 262.

Sergejchik, S. A. (1994). Ustojchivost' drevesnyh rastenij v tehnogennoj srede [The resistance of woody plants in a technogenic environment]. Nauka i tehnika, Minsk (in Russian).
Sergejchik, S. A., Sergejchik, A. A., \& Sidorovich, E. A. (1998). Ekologicheskaja fiziologija hvojnyh porod Belarusi v tehnogennoj srede [Ecological physiology of coniferous species in Belarus in a technogenic environment]. Belaruskaja Navuka, Minsk (in Russian).

Shlyk, A. A. (1963). Issledovanie metabolizma hlorofilla v zelenom rastenii radioizotopnym metodom [Research of a chlorophyll metabolism in a green plant by a radioisotope method]. Akademija Nauk SSSR, Institut Biohimii Imeni A. N. Baha, Moscow (in Russian).

Shmatkov, H. H., \& Minkov, Y. I. (2011). Otsinka zabrudnennia atmosfernoho povitria vykydamy pylu vid statsionarnykh dzherel promyslovykh pidpryiemstv, yaki roztashovani $\mathrm{v} \mathrm{m}$. Dnipropetrovsku [Assessment of atmospheric air pollution by dust from stationary sources of industrial enterprises located in Dnepropetrovsk]. Ekolohiia i Pryrodokorystuvannia, 14, 72-75 (in Ukrainian).

Shulman, M. V., Pakhomov, O. Y., \& Brygadyrenko, V. V. (2017). Effect of lead and cadmium ions upon the pupariation and morphological changes in Calliphora vicina (Diptera, Calliphoridae). Folia Oecologica, 44(1), 28-37.

Sklyarenko, A. V., \& Bessonova, V. P. (2018). Accumulation of sulfur and glutathione in leaves of woody plants growing under the conditions of outdoor air pollution by sulfur dioxide. Biosystems Diversity, 26(4), 334-338. http://doi.org/10.15421/011849

Smolikova, G. N., \& Medvedev, S. S. (2015). Karotinoidy semjan, sintez, raznoobrazie i funkcii [Seed carotenoids, synthesis, diversity and function]. Fiziologija Rastenij, 62(1), 3-16 (in Russian).

Strilets, R. O. (ed.). (2019). Ekolohichnyi pasport Dnipropetrovskoi oblasti za 2018 rik [Environmental passport of Dnipropetrovsk region for 2018]. Dnipro (in Ukrainian).

Suvorova, G. G., Oskorbina, M. V., Kopytova, L. D., Yankova, L. S., \& Popova, E. V. (2011). Sezonnye izmenenija fotosinteticheskoj aktivnosti i zelenyh pigmentov u sosny obyknovennoj i eli sibirskoj v optimume i ekstremal'nyh uslovijah uvlazhnenija [Seasonal changes in photosynthetic activity and green pigments in Scots pine and Siberian spruce under optimum and extreme conditions of moisture]. Sibirskij Jekologicheskij Zhurnal, 6, 851-859 (in Russian).

Tarabrin, V. P. (1980). Fiziologija ustojchivosti drevesnyh rastenij v uslovijah zagriaznenija okruzhajushhej sredy tiazhelymi metallami [The physiology of resistance of woody plants under environmental pollution by heavy metals]. In: Mikroelementy v Okruzhajushhej Srede. Naukova Dumka, Kiev. Pp. 17-19 (in Russian).

Tarchevskij, I. A. (2002). Signal'nye sistemy kletok rastenij [Signaling systems of plant cells]. Nauka, Moscow (in Russian).

Tuzhilkina, V. V., Bobkova, K. S., \& Martynyuk, Z. P. (1998). Hlorofill'nyj indeks i i fotosinteticheskij stok ugleroda $v$ hvojnye fitocenozy na evropejskom Severe Rossii [Chlorophyll index and photosynthetic carbon sink to coniferous phytocenoses in the European North of Russia]. Fiziologija Rastenij, 45(4), 594-600 (in Russian).

Tymko, S. M. (2016). Bioindikacionnoe znachenie koncentracii pigmentov v list’jah berezy povisloj v uslovijah gorodskoj sredy $\mathrm{g}$. Barnaula [Bioindication value of the concentration of pigments in birch leaves hanging in the urban environment of Barnaul]. Trudy Molodyh Uchenyh Altajskogo Universitetaju, 13, 30-34 (in Russian).

Tyutereva, E. V., Dmitrieva, V. A., \& Vojcehovskaya, O. V. (2017). Hlorofill b kak istochnik signalov, regulirujushhih razvitie i produktivnost' rastenij [Chlorophyll $\mathrm{b}$ as a source of signals regulating the development and productivity of plants]. Sel'skohozjajstvennaja Biologija, 52(5), 843-455 (in Russian).

Vieira, J., Matos, P., Mexia, T., Silva, P., Lopes, N., Freitas, C., Correia, O., Santos-Reis, M., Branquinho, C., \& Pinho, P. (2018). Green spaces are not all the same for the provision of air purification and climate regulation services: The case of urban parks. Environmental Research, 160, 306-313.

Wen, D., Kuang, Y., \& Zhou, G. (2004). Sensitivity analyses of woody species exposed to air pollution based on ecophysiological measurements. Environmental Science And Pollution Research, 11(3), 165-170.

Yahia, M. W., Johansson, E., Thorsson, S., Lindberg, F., \& Rasmussen, M. I. (2018) Effect of urban design on microclimate and thermal comfort outdoors in warmhumid Dar es Salaam. Tanzania. International Journal of Biometeorology, 62(3), 373-385. 